\title{
Praktyka kliniczna oceny minimalnej choroby resztkowej u chorych na szpiczaka plazmocytowego w Polsce: badanie ankietowe Polskiego Konsorcjum Szpiczakowego
}

\author{
Minimal residual disease assessment in plasma cell myeloma \\ patients in Poland: survey of the Polish Myeloma Consortium
}

Agnieszka Krzywdzińska ${ }^{1}$, Iwona Solarska ${ }^{2}$, Bartosz Puła ${ }^{3}$, Anna Czyż ${ }^{4}, 5$, Dominik Dytfeld ${ }^{5}$, Artur Jurczyszyn ${ }^{6}$, Agnieszka Balana-Nowak ${ }^{7}$, Krzysztof Giannopoulos $^{8}, 9$, Paulina Własiuk ${ }^{9}$, Anna Waszczuk-Gajda ${ }^{10}$, Maria Król11, Marek Dudziński ${ }^{12}$, Adrian Burdacki ${ }^{13}$, Tomasz Wróbel ${ }^{5}$, Donata Szymczak ${ }^{14}$, Olga Jankowska-Łęcka ${ }^{15}$, Paweł Bernatowicz ${ }^{16}$, Jan Zaucha ${ }^{17}$, Agata Tyczyńska ${ }^{17}$, Agnieszka Druzd-Sitek ${ }^{18}$, Piotr Centkowski ${ }^{19}$, Alina Świderska ${ }^{20}$, Elżbieta Rutkowska ${ }^{21}$, Krzysztof Lewandowskii2, Krzysztof Warzocha ${ }^{3}$, Krzysztof Jamroziak ${ }^{3}$

${ }^{1}$ Pracownia Immunofenotypowania, Zakład Diagnostyki Hematologicznej, Instytut Hematologii i Transfuzjologii, Warszawa; ${ }^{2}$ Pracownia Biologii Molekularnej, Zakład Diagnostyki Hematologicznej, Instytut Hematologii i Transfuzjologii, Warszawa; ${ }^{3}$ Klinika Hematologii, Instytut Hematologii i Transfuzjologii, Warszawa; ${ }^{4}$ Katedra i Klinika Hematologii i Transplantacji Szpiku, Uniwersytet Medyczny im. Karola Marcinkowskiego, Poznań; ${ }^{5}$ Klinika Hematologii, Nowotworów Krwi i Transplantacji Szpiku, Samodzielny Publiczny Szpital Kliniczny, Uniwersytet Medyczny, Wrocław; ${ }^{6}$ Klinika Hematologii, Collegium Medicum, Uniwersytet Jagielloński, Kraków;

${ }^{7}$ Pracownia Cytometrii Przepływowej, Zakład Diagnostyki Hematologicznej, Szpital Uniwersytecki, Kraków; ${ }^{8}$ Oddział Hematologiczny, Centrum Onkologii Ziemi Lubelskiej im. Św. Jana z Dukli, Lublin; ${ }^{9}$ Zakład Hematoonkologii

Doświadczalnej, Uniwersytet Medyczny, Lublin; ${ }^{10}$ Klinika Hematologii, Onkologii i Chorób Wewnętrznych,

Warszawski Uniwersytet Medyczny, Warszawa; ${ }^{11}$ Pracownia Cytometrii Przepływowej Kliniki Hematologii, Onkologii i Chorób Wewnętrznych, Warszawski Uniwersytet Medyczny, Warszawa; ${ }^{12}$ Klinika Hematologii, Wojewódzki Szpital Specjalistyczny im. Fryderyka Chopina, Rzeszów; ${ }^{13}$ Pracownia Cytometrii Przepływowej Kliniki Hematologii, Wojewódzki Szpital Specjalistyczny im. Fryderyka Chopina, Rzeszów; ${ }^{14}$ Pracownia Cytometrii Przepływowej, Samodzielny Publiczny Szpital Kliniczny, Uniwersytet Medyczny, Wrocław; ${ }^{15}$ Klinika Hematoonkologii

i Transplantacji Szpiku, Uniwersytet Medyczny, Lublin; ${ }^{16}$ Klinika Hematologii z Pododdziałem Chorób Naczyń, Uniwersytecki Szpital Kliniczny, Białystok; ${ }^{17}$ Gdyńskie Centrum Onkologii, Szpitale Wojewódzkie w Gdyni — Szpital Morski im. PCK, Gdynia; ${ }^{18}$ Klinika Nowotworów Układu Chłonnego, Centrum Onkologii — Instytut im. Marii Skłodowskiej-Curie, Warszawa; ${ }^{19}$ Oddział Onkologii Klinicznej i Hematologii, Wojewódzki Szpital Specjalistyczny, Biała Podlaska; ${ }^{20}$ Kliniczny Oddział Hematologii, Wojewódzki Szpital Kliniczny im. Karola Marcinkowskiego, Zielona Góra; ${ }^{21}$ Pracownia Cytometrii Przepływowej i Hematologii Kliniki Chorób Wewnętrznych i Hematologii, Wojskowy Instytut Medyczny, Warszawa; ${ }^{22}$ Laboratorium Hematologii, Uniwersyteckie Centrum Kliniczne, Gdańsk

Adres do korespondencji: Krzysztof Jamroziak, Klinika Hematologii, Instytut Hematologii i Transfuzjologii, ul. Indiry Gandhi 14, 02-776 Warszawa, tel. +48 223496 478, faks +48 223496 335, e-mail: krzysztof.jamroziak@wp.pl 


\title{
Streszczenie
}

W badaniach nad znaczeniem minimalnej choroby resztkowej (MRD) w szpiczaku plazmocytowym (PCM) dowiedziono, że status MRD ma wartość prognostyczna niezależie od zastosowanego leczenia. W celu poznania zasad monitorowania MRD u chorych na PCM w polskich ośrodkach hematologicznych przeprowadzono badanie ankietowe. W ankiecie zadano pytania dotyczace stosowanych metod wykrywania MRD oraz punktów czasowych, w których badania sq wykonywane. W $7 z 15$ ośrodków objętych badaniem ankietowym oznaczenia MRD u chorych na PCM wykonuje sie $w$ aspiratach szpiku kostnego metodq cytometrii przeptywowej (FC). We wszystkich ośrodkach oznaczenia FC-MRD sq wykonywane jedynie u chorych w catkowitej remisji (CR), jednak w różnych punktach czasowych — tylko po przeszczepieniu autologicznych krwiotwórczych komórek macierzystych (auto-HSCT), po auto-HSCT $i$ konsolidacji, po zakończeniu leczenia pierwszej linii lub, w przypadku uzyskania CR, po dowolnej linii leczenia. Stwierdzono ponadto znaczne różnice $w$ sposobie wykonywania badania FC-MRD wplywajace na osiagana czutość detekcji MRD (od $10^{-3}$ do $\left.10^{-5}\right)$. W żadnym z ankietowanych ośrodków nie ocenia się MRD w szpiku kostnym technikami molekularnymi. Monitorowanie MRD metodami obrazowymi stosuje się $w 8 z 15$ ośrodków. Wyniki przeprowadzonej ankiety moga postuzyć wypracowaniu wspólnych wytycznych $i$ standaryzacji oceny MRD u chorych na PCM w Polsce.

Słowa kluczowe: szpiczak plazmocytowy, minimalna choroba resztkowa, cytometria przepływowa, sekwencjonowanie

Hematologia 2017; 8, 4: 239-245

\begin{abstract}
Studies exploring the significance of minimal residual disease (MRD) in plasma cell myeloma (PCM) have proven its prognostic value, regardless of the type of administered treatment. In order to assess the current practice for evaluating MRD in Poland, we conducted a survey on the methods for assessing MRD and on the MRD testing time points at Polish hematological centres. Seven out of 15 institutions surveyed use of the flow cytometry (FC) method for MRD assessment. The FC-MRD assessment is performed uniformly only in those patients achieving complete remission (CR). However, the specific indications and assessment time points differed at the tested centres including: testing MRD only after autologous hematopoietic stem cell transplantation (auto-HSCT), after auto-HSCT and consolidation, after completion of first line chemotherapy or after obtaining $C R$ in any line of treatment. The study also showed considerable heterogeneity in the FC-MRD methodology, which affects test sensitivity (from $10^{-3}$ to $10^{-5}$ ). None of the surveyed centres uses molecular techniques for MRD assessment. In 8 of the 15 institutions, patients are monitored by imaging techniques. Our survey may thus be useful for developing guidelines and standardization of MRD assessment in PCM in Poland.
\end{abstract}

Key words: plasma cell myeloma, minimal residual disease, flow cytometry, gene sequencing Hematologia 2017; 8, 4: 239-245

\section{Wprowadzenie}

W wyniku intensywnych badań nad biologią szpiczaka plazmocytowego (PCM, plasma cell myeloma), w szczególności nad złożonymi mechanizmami oporności na klasyczną chemioterapię, w ostatnich dwóch dekadach udało się opracować oraz wprowadzić do praktyki klinicznej kilka nowych klas leków przeciwnowotworowych, w tym inhibitory proteasomu, leki immunomodulujące, przeciwciała monoklonalne i inhibitory deacetylazy histonów. Dzięki zastosowaniu kombinacji nowych leków osiągnięto imponujący postęp terapeutyczny, wyrażający się coraz większym odsetkiem głębokich i długotrwałych odpowiedzi klinicznych, co spowodowało globalną poprawę rokowania chorych na PCM. Należy podkreślić, że zastosowanie schematów chemioterapii zawierających leki 
o różnych mechanizmach działania, w połączeniu $z$ terapią dużymi dawkami melfalanu, wspomaganą przeszczepieniem autologicznych krwiotwórczych komórek macierzystych (auto-HSCT, autologous hematopoetic stem cell transplantation), umożliwia obecnie osiagnięcie odpowiedzi na leczenie u niemal wszystkich chorych. W niektórych badaniach klinicznych zastosowanie najbardziej skutecznych kombinacji leków pozwala osiągnąć całkowite remisje (CR) nawet u $70 \%$ chorych $[1,2]$.

Dostęp do bardziej skutecznych schematów terapeutycznych oraz gromadzone coraz liczniejsze dowody korzystnego znaczenia prognostycznego znacznego zmniejszenia masy nowotworu stały się przyczyną aktualizacji kryteriów odpowiedzi na terapię PCM w celu sformułowania lepszej definicji CR. W rekomendacjach Międzynarodowej Grupy Roboczej ds. Szpiczaka (IMWG, International Myeloma Working Group) z 2011 roku po raz pierwszy zaproponowano kategorie odpowiedzi uwzględniające ocenę tak zwanej minimalnej choroby resztkowej (MRD, minimal residual disease) $\mathrm{w}$ aspiracie szpiku, tj.: immunofenotypowa (immunophenotypic CR) i molekularna CR (molecular $C R$ ), określane odpowiednio przy użyciu co najmniej 4-kolorowej cytometrii przepływowej (FC, flow cytometry) oraz specyficznej dla allelu reakcji łańcuchowej polimerazy oligonukleotydu (ASO-PCR, allele-specific oligonucleotide polymerase chain reaction) [3]. Zastosowanie tych technik umożliwiło oznaczanie MRD z czułością odpowiednio $10^{-4}$ i $10^{-5}$, co oznacza możliwość detekcji jednej komórki PCM wśród 10 tys. i 100 tys. komórek szpiku.

Ilościowe oznaczenie resztkowych komórek PCM umożliwiło bardzo precyzyjną ocenę efektywności nowych leków i różnych schematów terapii. Niezależnie od zastosowanej techniki poziom MRD okazał się niezależnym czynnikiem prognostycznym czasu przeżycia pacjentów. Rawstron i wsp. [4], oznaczając MRD metodą cytometryczną u pacjentów po auto-HSCT, wykazali, że obecność MRD ponad $0,01 \%$ istotnie wplywa na czas wolny od progresji (PFS, progression-free survival) $(15,5$ v. 28,6 miesiąca; $\mathrm{p}<0,001)$ i całkowitego przeżycia (OS, overall survival) (59 v. 80,6 miesiąca; $\mathrm{p}=0,018)$. Udowodniono również, że wpływ statusu MRD na wskaźniki przeżycia jest niezależny od grupy ryzyka cytogenetycznego [4, 5]. Wyniki obserwacji Ferrero i wsp. [6] wskazują $z$ kolei na użyteczność monitorowania MRD w ocenie efektywności leczenia konsolidującego i podtrzymującego remisję oraz wczesnego wykrywania nawrotu. Osiągnięcie immunofenotypowej CR w wyniku zastosowanego leczenia istotnie wydłuża PFS i czas do progresji
(TTP, time to progression) w grupie chorych powyżej 65. roku życia [7] oraz z nawrotowym PCM [8]. Paiva i wsp. [8] sugerują również, że — ze względu na ryzyko wznowy pozaszpikowej - w ocenie odpowiedzi po auto-HSCT powinno się uwzględniać również badania obrazowe metodą pozytonowej tomografii emisyjnej/tomografii komputerowej (PET/CT, positron emission tomography/computed tomography). Wraz z rozwojem technik biologii molekularnej i FC pojawiła się możliwość jeszcze bardziej specyficznego i czułego wykrywania przetrwałych komórek PCM. Badania $z$ czułością $10^{-5}$ i większą wzmocniły znaczenie prognostyczne oceny poziomu MRD u chorych na PCM $[9,10]$.

W najnowszych rekomendacjach IMWG z 2016 roku wprowadzono kategorie oceny odpowiedzi na terapię w PCM oparte na badaniu MRD w szpiku $z$ czułością co najmniej $10^{-5}$ [11]. Założono w nich zastosowanie $\mathrm{w}$ tym celu najnowocześniejszych technik diagnostycznych — tak zwanej cytometrii przepływowej nowej generacji (NGF, next generation flow) i sekwencjonowanie nowej generacji (NGS, next generation sequencing) oraz, po raz pierwszy w ocenie MRD, uwzględniono również badania obrazowe. Zaleca się, by ocenę MRD przeprowadzać po kolejnych etapach leczenia, tj. indukcji, auto-HSCT, konsolidacji i leczeniu podtrzymującym, ograniczając ją tylko do pacjentów w CR. Ponieważ kluczowe dla wiarygodności badania są jakość aspiratu szpiku i liczba analizowanych komórek, to należy do niego przeznaczać próbkę z pierwszej aspiracji w objętości około $2 \mathrm{ml}$. Nie należy przekraczać objętości $4-5 \mathrm{ml}$ ze względu na możliwość rozcieńczenia krwią [11].

Potrzeba wypracowania standardu oceny MRD u chorych na PCM jest obecnie jednym $z$ najczęściej poruszanych zagadnień na międzynarodowych i krajowych konferencjach oraz $\mathrm{w}$ publikacjach naukowych poświęconych PCM [12, 13]. Doświadczenia grup badaczy $z$ Wielkiej Brytanii i Hiszpanii jednoznacznie wskazują na celowość stosowania nowych kryteriów odpowiedzi w badaniach klinicznych, jednak zasadności podejmowania decyzji terapeutycznych na podstawie wyniku oceny MRD w rutynowej praktyce klinicznej jeszcze nie udowodniono. Co istotne, wprowadzenie kategorii MRD do najbardziej uznawanych na świecie kryteriów odpowiedzi publikowanych przez IMWG wskazuje na konieczność stosowania oceny MRD również w Polsce.

Mimo że kryteria oparte na badaniu MRD istnieją już od 2011 roku, to według wiedzy autorów nie było doniesień o zakresie i sposobie przeprowadzania oceny tego parametru w Polsce. Ponadto, 
ze względu na wymagane przy wykonywaniu tak wyspecjalizowanego i czasochłonnego badania wyposażenie i doświadczenie, a jednocześnie stosunkowo niewielką liczbę takich badań, niezbędna wydaje się standaryzacja, a także — być może częściowa centralizacja oceny MRD u chorych na PCM w Polsce. W związku $z$ tym, w ramach Polskiego Konsorcjum Szpiczakowego (PMC, Polish Myeloma Consortium), przeprowadzono badanie ankietowe, którego celem było poznanie obecnej praktyki klinicznej, potrzeb i możliwości technicznych oznaczania MRD u chorych na PCM w Polsce.

\section{Metodyka}

Ankieta „Ocena choroby resztkowej w szpiczaku plazmocytowym w polskich ośrodkach hematologicznych" została przygotowana w formie elektronicznego arkusza danych i rozesłana drogą elektroniczną do polskich ośrodków hematologicznych prowadzących terapię szpiczaka (tab. 1). Ankietę tę podzielono tematycznie na dwie części — kliniczną oraz laboratoryjną. W części klinicznej zawarto pytania służące określeniu możliwości oceny MRD w danym ośrodku. Pytania dotyczyły między innymi rodzaju stosowanej techniki badawczej, punktów czasowych oraz etapów leczenia, w których są wykonywane oznaczenia MRD. Ponadto w części klinicznej były zawarte pytania służące zbadaniu opinii ośrodka na temat oceny MRD u chorych na PCM $z$ uwzględnieniem preferowanej metody (FC, NGS, PET/CT, rezonans magnetyczny [MRI, magnetic resonance imaging]), grup badanych pacjentów (m.in. kwalifikujących się oraz niekwalifikujących do auto-HSCT), punktów czasowych badania $\mathrm{w}$ odniesieniu do etapu stosowanego leczenia czy możliwości oraz konieczności standaryzacji badań laboratoryjnych i obrazowych stosowanych w ocenie MRD. Część laboratoryjna ankiety zawierała pytania na temat sposobu oraz technicznych możliwości oznaczania MRD u chorych na PCM metodą FC. Pytania dotyczyły typu posiadanego cytometru przepływowego, rodzaju i liczby antygenów stosowanych w identyfikacji plazmocytów, używanego protokołu, jak również decydujących o czułości badania liczby wszystkich zbieranych komórek i minimalnej liczby komórek o nieprawidłowym fenotypie uznawanych za populację patologiczną.

\section{Wyniki}

Odpowiedzi otrzymano od 15 spośród 17 ośrodków, do których wysłano ankiety (88\%), przy czym w 5 przypadkach uzyskano odpowiedzi
Tabela 1. Wykaz ośrodków uczestniczących w badaniu ankietowym

Table 1. The list of centers participating in the survey

Katedra i Klinika Hematologii i Transplantacji Szpiku, Uniwersytet Medyczny im. Karola Marcinkowskiego, Poznań

Klinika Hematoonkologii i Transplantacji Szpiku, Uniwersytet Medyczny, Lublin

Klinika Hematologii, Wojewódzki Szpital Specjalistyczny im. Fryderyka Chopina, Rzeszów

Klinika Hematologii, Collegium Medicum, Uniwersytet Jagielloński, Kraków

Klinika Hematologii, Onkologii i Chorób Wewnętrznych, Warszawski Uniwersytet Medyczny, Warszawa

Klinika Hematologii, Instytut Hematologii

i Transfuzjologii, Warszawa

Oddział Hematologiczny, Centrum Onkologii

Ziemi Lubelskiej im. św. Jana z Dukli, Lublin

Klinika Hematologii, Nowotworów Krwi i Transplantacji

Szpiku, Samodzielny Publiczny Szpital Kliniczny,

Uniwersytet Medyczny, Wrocław

Kliniczny Oddział Hematologii, Wojewódzki Szpital Kliniczny im. Karola Marcinkowskiego, Zielona Góra

Oddział Onkologii Klinicznej i Hematologii, Wojewódzki Szpital Specjalistyczny, Biała Podlaska

Klinika Hematologii z Pododdziałem Chorób Naczyń, Uniwersytecki Szpital Kliniczny, Białystok

Gdyńskie Centrum Onkologii, Szpitale Wojewódzkie w Gdyni - Szpital Morski im. PCK

Klinika Nowotworów Układu Chłonnego, Centrum Onkologii - Instytut im. Marii Skłodowskiej-Curie, Warszawa

Klinika Chorób Wewnętrznych i Hematologii, Wojskowy Instytut Medyczny, Warszawa

Laboratorium Hematologii, Uniwersyteckie Centrum Kliniczne, Gdańsk

dotyczące wyłącznie części klinicznej, a w 2 przypadkach — wyłącznie części laboratoryjnej ankiety. Stwierdzono, że obecnie ocena MRD u chorych na PCM w jakimkolwiek zakresie jest wykonywana w 7 spośród 15 badanych ośrodków. Pozostałe ośrodki deklarują potrzebę wykonywania badań monitorujących MRD motywowaną koniecznością zwiększenia czułości metod oceny odpowiedzi na prowadzone leczenie. W związku $z$ tym $\mathrm{w}$ pozostałych 8 ośrodkach planuje się wprowadzenie takich badań w macierzystym ośrodku (3/8) lub, ze względu na brak dostępności do odpowiedniego sprzętu lub wyszkolonego personelu, zlecanie tego rodzaju badań innym jednostkom (5/8).

Sześć z 7 ośrodków, w których jest przeprowadzana ocena MRD, odpowiedziało na pytania części klinicznej dotyczącej kryteriów wyboru 
pacjentów, etapu terapii i sposobu przeprowadzania oceny MRD. We wszystkich przypadkach przy kwalifikacji pacjenta do oceny MRD stosuje się kryterium uzyskania CR lub rygorystycznej całkowitej remisji (sCR, stringent $C R$ ). Punkty czasowe terapii, w których badanie jest wykonywane, są jednak zróżnicowane. W 3 przypadkach badaniem są obejmowani tylko chorzy po auto-HSCT (3/6), w tym w jednym $z$ ośrodków - dodatkowo po leczeniu konsolidującym. W 2 kolejnych ośrodkach badanie wykonuje się po zakończeniu leczenia dowolnej linii $(2 / 6)$. W jednym ośrodku natomiast do badania MRD są kwalifikowani wszyscy chorzy w CR zarówno po pierwszej, jak i po kolejnych liniach leczenia oraz po auto-HSCT. Badanie MRD we wszystkich tych przypadkach jest wykonywane metodą FC (6/6).

Metody obrazowe są wykorzystywane do monitorowania przebiegu PCM po uzyskaniu odpowiedzi w 8 spośród 13 ośrodków, których personel uzupełnił część kliniczną ankiety. W 5 z nich (5/8) wykorzystuje się w tym celu badanie MRI wykonywane regularnie co około 12 miesięcy lub po uzyskaniu odpowiedzi na dowolną linię leczenia. W 4 ośrodkach (4/8) ocenę przeprowadza się na podstawie wyniku badania PET/CT. Jest ono zlecane u wszystkich pacjentów po uzyskaniu odpowiedzi na dowolną linię leczenia lub po auto-HSCT (2/4) albo jest ograniczane do monitorowania pacjentów tylko ze szpiczakiem niewydzielającym (2/4).

Wyniki ankiety potwierdziły przydatność kliniczną oceny MRD u chorych na PCM - wszyscy biorący w niej udział dostrzegają potrzebę opracowania jednolitych wytycznych i standaryzacji postępowania w tym zakresie. Wśród 13 klinicystów odpowiadających na pytania odnośnie do wyboru grupy pacjentów i momentu możliwej oceny MRD większość (9/13) opowiedziała się za wykonywaniem badania u wszystkich pacjentów, którzy uzyskali odpowiedź na poziomie co najmniej CR niezależnie od linii leczenia. Ponadto przedstawiciele 3 ośrodków zaproponowali monitorowanie MRD $\mathrm{w}$ regularnych odstępach czasu. Za ograniczeniem badania MRD tylko do osób kwalifikujących się do auto-HSCT opowiedział się personel 4 ośrodków (4/13). W jednym $z$ nich zaproponowano ocenę tylko po auto-HSCT, personel 2 - po zakończeniu leczenia dowolnej linii i po auto-HSCT, natomiast personel trzeciego ośrodka - po skutecznym leczeniu indukcyjnym (kryterium $\mathrm{CR}$ ) i po przeszczepieniu oraz za zgodą chorego, kontrolnie raz $\mathrm{w}$ roku w przypadku utrzymującej się $\mathrm{w}$ badaniach laboratoryjnych CR.

Najbardziej dostępną i preferowaną techniką monitorowania MRD pozostaje FC. Jak wynika z przeprowadzonej ankiety, wszystkie ośrodki mogą mieć dostęp do tego rodzaju badań, posiadając własne pracownie (10/15) lub zlecając badania laboratoriom zewnętrznym (5/15). Ocena MRD technikami molekularnymi ASO-PCR czy NGS byłaby możliwa tylko w 3 przypadkach.

Odpowiedzi na pytania części laboratoryjnej ankiety autorzy niniejszej pracy otrzymali z 10 pracowni cytometrycznych. W $7 \mathrm{z}$ nich (7/10) u chorych na PCM wykonuje się ocenę fenotypu komórek plazmatycznych przy rozpoznaniu oraz ocenę MRD. W 3 laboratoriach planuje się wdrożenie badań MRD w przyszłości. Dziewięć (9/10) pracowni dysponuje obecnie aparatami 3-laserowymi umożliwiającymi stosowanie 8-kolorowych zestawów przeciwciał.

Wykonywanie badania MRD z użyciem 3-5 kolorów deklarują obecnie 3 ośrodki (3/10). W tych przypadkach czułość oznaczeń wynosi $10^{-3}-10^{-4}$, a liczba analizowanych komórek to 100-200 tys. Jedno laboratorium podało minimalną liczbę komórek, jaka jest uznawana za populację patologiczną. Pozostałe laboratoria, w których wykonuje się lub planuje badanie $z$ użyciem 8-kolorowej cytometrii, deklarują różny próg detekcji MRD $\left(10^{-3}-10^{-5}\right)$. Decydujące o czułości testu liczba wszystkich zbieranych komórek oraz ich minimalna liczba konieczna do stwierdzenia klonu PCM są w tych pracowniach wyraźnie zróżnicowane i wynoszą odpowiednio 100 tys. -2 mln oraz $20-100$. W 5 pracowniach $(5 / 10) \mathrm{w}$ panelach przeciwciał przewiduje się ocenę wszystkich zalecanych obecnie antygenów. W pozostałych najczęściej pomija się CD27, CD117 i CD81, natomiast dodatkowo plazmocyty nowotworowe są identyfikowane poprzez ocenę ekspresji CD20, CD28, CD13, CD33 i $\beta_{2}$-mikroglobuliny. Tylko 2 z 7 laboratoriów deklarujących wykonywanie badania MRD u chorych na PCM spełniają wszystkie metodyczne zalecenia Międzynarodowego Towarzystwa Cytometrii Klinicznej (ICCS, International Clinical Cytometry Society) i Europejskiego Towarzystwa Klinicznej Analizy Komórek (ESCCA, European Society for Clinical Cell Analysis) dotyczące oznaczeń z czułością na poziomie $10^{-5}$.

\section{Dyskusja}

Bardziej skuteczna terapia chorych na PCM przyczyniła się do znaczącej poprawy jakości osiąganych odpowiedzi, a wyniki badań nad najnowszymi lekami, w tym inhibitorami proteasomu kolejnych generacji i przeciwciałami monoklonalnymi anty-CD38, dają nadzieję na dalszy postęp 
w leczeniu i uzyskiwanie trwałych i głębokich odpowiedzi [1, 14]. Badania MRD z zastosowaniem wieloparametrowej FC i technik molekularnych (ASO-PCR, NGS), umożliwiających wykrywanie klonalnych plazmocytów $z$ czułością $10^{-4}-10^{-6}$, jednoznaczne wskazują, że taka głębokość odpowiedzi koreluje dodatnio $z$ parametrami przeżycia chorych, niezależnie od rodzaju zastosowanej chemioterapii, wieku pacjenta czy stadium choroby $[12,13,15]$.

Wprowadzenie przez IMWG nowych kryteriów głębokich odpowiedzi, uwzgledniających ocenę MRD z czułością co najmniej $10^{-5}$, wskazuje na to, że dążenie do eradykacji MRD powinno być jednym $z$ istotnych celów nowoczesnej terapii u chorych na PCM. Pociąga to za sobą konieczność wprowadzenia czułych metod monitorowania MRD w referencyjnych ośrodkach hematologicznych. Szczegółowe wytyczne odnośnie do metodyki cytometrycznego badania MRD, pozwalające na osiągnięcie tak wysokiego progu czułości, opracowali i opublikowali eksperci ICCS i ESCCA [16-19]. W wytycznych tych uznano, że w identyfikacji prawidłowych i szpiczakowych komórek plazmatycznych najbardziej specyficznymi markerami są antygeny: CD38, CD138, CD45, CD19, CD27, CD56, CD81, CD117, oraz cytoplazmatyczna ekspresja łańcuchów lekkich kappa i lambda. Zastosowanie przeciwciał przeciwko powyższym antygenom, w co najmniej 8-kolorowym barwieniu, gwarantuje wykrycie immunofenotypowych aberracji plazmocytów niemal u wszystkich chorych na PCM oraz wysoką specyficzność przy poszukiwaniu MRD [17]. Czynnikami decydującymi o czułości testu są jakość aspiratu i liczba analizowanych komórek szpiku. Zakładana czułość badania $10^{-5}$ oznacza konieczność akwizycji minimum 2 mln komórek, przy czym badanie ilościowe MRD wymaga analizy 5 mln komórek szpiku [18]. W zaleceniach ISCCA/ /ESSCA podano także sposób określania czułości oraz raportowania wyniku badania [19].

Opisując nowe kategorie odpowiedzi, IMWG odnosi się również do samej metodyki badania MRD, podkreślając istotność walidacji i standaryzacji stosowanych procedur. W przypadku cytometrii i oznaczeń $z$ czułością $10^{-5}$ rekomenduje się NGF oraz w pełni zwalidowany protokół badania proponowany przez konsorcjum EuroFlow [11]. Spełnia on wszystkie zalecenia ICCS/ESCCA, a dodatkowo standaryzuje sposób konfiguracji cytometru, optymalizuje panel przeciwciał (w zakresie klonów i fluorochromów) oraz precyzuje sposób przygotowania i akwizycji próbki. Analiza danych z zastosowaniem odpowiedniego oprogramowania gwarantuje wysoką specyficzność i powtarzalność oznaczenia oraz zwiększa próg detekcji komórek PCM do $10^{-6}$ [20].

Jak wskazują wyniki przeprowadzonego badania, $46 \%$ ankietowanych ośrodków hematologicznych monitoruje swoich pacjentów, oceniając odsetek komórek PCM w szpiku z zastosowaniem FC. Mimo że wszystkie pracownie cytometryczne, które wzięły udział w badaniu, dysponują aparatami umożliwiającymi równoczesną ocenę przynajmniej sześciu fluorescencji, to personel $3 \mathrm{z}$ nich deklarował ocenę MRD z użyciem 3-5-kolorowego barwienia. Wiąże się to nie tylko $z$ mniejszą czułością badania $\left(10^{-3}-10^{-4}\right)$, ale także ogranicza jego specyficzność ze względu na heterogenność fenotypu plazmocytów prawidłowych i szpiczakowych, w tym możliwość występowania więcej niż jednego klonu komórek PCM, oraz stwarza trudności w wiarygodnym określeniu klonalności [20]. Odpowiedzi udzielone $\mathrm{w}$ ramach części metodycznej ankiety ujawniły znaczne rozbieżności w sposobie określania czułości oznaczeń. Deklarowane czułości badania $z$ użyciem ośmiu antygenów różnią się między laboratoriami nawet 100 -krotnie (od 0,1\% do $0,001 \%)$ i wynikają $z$ różnic $\mathrm{w}$ zakresie liczby zbieranych komórek oraz przyjętej minimalnej liczby zdarzeń wskazujących na populację komórek PCM. Podobne rozbieżności w osiaganych progach detekcji wykazały wyniki badań przeprowadzonych wśród 11 laboratoriów, w których badanie MRD $\mathrm{u}$ chorych na PCM wykonuje się w Stanach Zjednoczonych [21]. Wśród laboratoriów wykorzystujących w tym celu od 5 do 9 kanałów fluorescencji zakres osiąganych maksymalnych czułości wynosił od $0,02 \%$ do $0,0005 \%$. Flanders i wsp. [21] zwracają ponadto uwagę na różnice w doborze przeciwciał i sposobie definiowania patologicznych komórek PCM. Opracowana przez autorów niniejszej pracy ankieta nie zawierała szczegółowych pytań na temat sposobu analizy. Natomiast $z$ oceny stosowanych w badaniu antygenów wynika, że wszystkie laboratoria stosują markery o udowodnionej swoistości, a w detekcji plazmocytów prawidłowych i szpiczakowych CD138+CD38+ wykorzystują aberrantną ekspresję co najmniej trzech antygenów błonowych: CD19, CD45, CD56, oraz cytoplazmatycznych łańcuchów lekkich. Wszystkie dodatkowe zalecane obecnie antygeny CD27, CD81 i CD117 są badane w 5 z 10 laboratoriów.

Ze względu na dostępność i koszty badania FC wydaje się techniką możliwą do zastosowania w standaryzacji wykrywania MRD we wszystkich ośrodkach hematologicznych w Polsce. Osiaggnięcie wysokiej czułości oznaczeń MRD oraz wiarygodnych, porównywalnych między laboratoriami, 
wyników będzie wymagać przyjęcia jednolitych wytycznych sposobu przeprowadzania testu na podstawie najnowszych rekomendacji [16-19]. Standaryzacji wymagają przede wszystkim panel stosowanych przeciwciał, protokół przygotowania próbki umożliwiający akwizycję 2-5 mln komórek oraz sposób definiowania uzyskiwanej czułości. $\mathrm{O}$ wiarygodności oznaczeń będą w głównej mierze decydować jakość aspiratu szpiku i doświadczenie diagnosty przeprowadzającego analizę. Autorzy niniejszej pracy wyrażają nadzieję, że wyniki przeprowadzonej ankiety przyczynią się do upowszechnienia i standaryzacji oceny MRD w polskich ośrodkach hematologicznych, co wpłynie korzystnie na wyniki leczenia PCM.

\section{Piśmiennictwo}

1. Jakubowiak AJ, Dytfeld D, Griffith KA, et al. A phase $1 / 2$ study of carfilzomib in combination with lenalidomide and low-dose dexamethasone as a frontline treatment for multiple myeloma. Blood. 2012; 120(9): 1801-1809, doi: 10.1182/blood-2012-04-422683, indexed in Pubmed: 22665938.

2. Kumar S, Flinn I, Richardson PG, et al. Randomized, multicenter, phase 2 study (EVOLUTION) of combinations of bortezomib, dexamethasone, cyclophosphamide, and lenalidomide in previously untreated multiple myeloma. Blood. 2012; 119(19): 4375-4382, doi: 10.1182/blood-2011-11-395749, indexed in Pubmed: 22422823.

3. Rajkumar SV, Harousseau JL, Durie B, et al. International Myeloma Workshop Consensus Panel 1. Consensus recommendations for the uniform reporting of clinical trials: report of the International Myeloma Workshop Consensus Panel 1. Blood. 2011; 117(18): 4691-4695, doi: 10.1182/blood-2010-10-299487, indexed in Pubmed: 21292775.

4. Rawstron AC, Child JA, de Tute RM, et al. Minimal residual disease assessed by multiparameter flow cytometry in multiple myeloma: impact on outcome in the Medical Research Council Myeloma IX Study. J Clin Oncol. 2013; 31(20): 2540-2547, doi: 10.1200/JCO.2012.46.2119, indexed in Pubmed: 23733781.

5. Paiva B, Gutiérrez NC, Rosiñol L, et al. PETHEMA/GEM (Programa para el Estudio de la Terapéutica en Hemopatías Malignas/Grupo Español de Mieloma) Cooperative Study Groups. High-risk cytogenetics and persistent minimal residual disease by multiparameter flow cytometry predict unsustained complete response after autologous stem cell transplantation in multiple myeloma. Blood. 2012; 119(3): 687-691, doi: 10.1182/ /blood-2011-07-370460, indexed in Pubmed: 22128143.

6. Ferrero S, Ladetto M, Drandi D, et al. Long-term results of the GIMEMA VEL-03-096 trial in MM patients receiving VTD consolidation after ASCT: MRD kinetics' impact on survival. Leukemia. 2015; 29(3): 689-695, doi: 10.1038/leu.2014.219, indexed in Pubmed: 25027515.

7. Paiva B, Martinez-Lopez J, Vidriales MB, et al. Comparison of immunofixation, serum free light chain, and immunophenotyping for response evaluation and prognostication in multiple myeloma. J Clin Oncol. 2011; 29(12): 1627-1633, doi: 10.1200/ /JCO.2010.33.1967, indexed in Pubmed: 21402611.

8. Paiva B, Chandia M, Puig N, et al. The prognostic value of multiparameter flow cytometry minimal residual disease assessment in relapsed multiple myeloma. Haematologica. 2015; 100(2): e53-e55, doi: 10.3324/haematol.2014.115162, indexed in Pubmed: 25381128.

9. Rawstron AC, Gregory WM, de Tute RM, et al. Minimal residual disease in myeloma by flow cytometry: independent prediction of survival benefit per log reduction. Blood. 2015; 125(12): 1932-1935, doi: 10.1182/blood-2014-07-590166, indexed in Pubmed: 25645353.

10. Martinez-Lopez J, Lahuerta JJ, Pepin F, et al. Prognostic value of deep sequencing method for minimal residual disease detection in multiple myeloma. Blood. 2014; 123(20): 3073-3079, doi: 10.1182/ /blood-2014-01-550020, indexed in Pubmed: 24646471.

11. Kumar S, Paiva B, Anderson KC, et al. International Myeloma Working Group consensus criteria for response and minimal residual disease assessment in multiple myeloma. Lancet Oncol. 2016; 17(8): e328-e346, doi: 10.1016/S1470-2045(16)30206-6, indexed in Pubmed: 27511158.

12. Sanchez-Vega B, Ayala R, Cedena T, et al. Minimal residual disease testing for multiple myeloma. Hematologia. 2017; 8(3): 219-227.

13. Rihova L, Hajek R. Flow cytometric minimal residual disease assessment in multiple myeloma. Hematologia. 2017; 8(3): 211-218.

14. Dimopoulos MA, Oriol A, Nahi H, et al. POLLUX Investigators. Daratumumab, lenalidomide, and dexamethasone for multiple myeloma. N Engl J Med. 2016; 375(14): 1319-1331, doi: 10.1056/ /NEJMoa1607751, indexed in Pubmed: 27705267.

15. Nishihori T, Song J, Shain KH. Minimal residual disease assessment in the context of multiple myeloma treatment. Curr Hematol Malig Rep. 2016; 11(2): 118-126, doi: 10.1007/s11899-0160308-3, indexed in Pubmed: 26898557.

16. Oldaker TA, Wallace PK, Barnett D. Flow cytometry quality requirements for monitoring of minimal disease in plasma cell myeloma. Cytometry B Clin Cytom. 2016; 90(1): 40-46, doi: 10.1002/ /cyto.b.21276, indexed in Pubmed: 26201282.

17. Flores-Montero J, de Tute R, Paiva B, et al. Immunophenotype of normal vs. myeloma plasma cells: toward antibody panel specifications for MRD detection in multiple myeloma. Cytometry B Clin Cytom. 2016; 90(1): 61-72, doi: 10.1002/cyto.b.21265, indexed in Pubmed: 26100534.

18. Stetler-Stevenson M, Paiva B, Stoolman L, et al. Consensus guidelines for myeloma minimal residual disease sample staining and data acquisition. Cytometry B Clin Cytom. 2016; 90(1): 26-30, doi: 10.1002/cyto.b.21249, indexed in Pubmed: 25907102.

19. Arroz M, Came N, Lin P, et al. Consensus guidelines on plasma cell myeloma minimal residual disease analysis and reporting. Cytometry B Clin Cytom. 2016; 90(1): 31-39, doi: 10.1002/ /cyto.b.21228, indexed in Pubmed: 25619868.

20. Rawstron AC, Orfao A, Beksac M, et al. European Myeloma Network. Report of the European Myeloma Network on multiparametric flow cytometry in multiple myeloma and related disorders. Haematologica. 2008; 93(3): 431-438, doi: 10.3324/ /haematol.11080, indexed in Pubmed: 18268286.

21. Flanders A, Stetler-Stevenson M, Landgren O. Minimal residual disease testing in multiple myeloma by flow cytometry: major heterogeneity. Blood. 2013; 122(6): 1088-1089, doi: 10.1182/ /blood-2013-05-506170, indexed in Pubmed: 23929839. 